\title{
Planting density, hydrodynamic exposure and mussel beds affect survival of transplanted intertidal eelgrass
}

\author{
Arthur R. Bos ${ }^{1,2, *}$, Marieke M. van Katwijk ${ }^{1}$ \\ ${ }^{1}$ Department of Environmental Science, Institute for Wetland and Water Research, Radboud University, PO Box 9010 , \\ 6500 GL Nijmegen, The Netherlands \\ ${ }^{2}$ Davao del Norte State College, New Visayas, 8105 Panabo City, Philippines
}

\begin{abstract}
Transplantation of eelgrass Zostera marina has become a promising restoration tool since natural recolonisation during the last century failed after massive mortality, due to a combination of a wasting disease outbreak and a sequence of human impacts. We studied the interactive effects of planting density and hydrodynamic exposure on the survival of transplants of an annual population of intertidal eelgrass. Accordingly, eelgrass seedlings were planted in high density (HD: 14 plants $\mathrm{m}^{-2}$ ) and low density (LD: 5 plants $\mathrm{m}^{-2}$ ) units at 3 locations with varied wave and current exposures. We also tested the potential of blue mussel beds (Mytilus edulis) to facilitate eelgrass survival. Transplant survival decreased as hydrodynamic exposure increased. Survival was high $(75 \%$ after $7 \mathrm{wk}$ ) at the low exposure location. The intermediate exposure location had slightly lower overall survival ( $60 \%$ after $7 \mathrm{wk})$, and lowest overall survival rate was at the most exposed location $(20 \%$ after $7 \mathrm{wk}$ ). Facilitation existed among eelgrass plants. Survival was significantly higher in the HD units than in the LD units at both high and intermediate exposure locations. Planting density had no effect on survival at the low exposure location. Hence, there was an interactive effect of planting density, hydrodynamic exposure and shelter. Eelgrass planted in open spaces within a mussel bed survived significantly better than transplants situated $60 \mathrm{~m}$ seaward of the mussel bed. Thus, mussel beds facilitate eelgrass survival. The insights into the processes affecting transplantation success will be of use in eelgrass restoration around the world.
\end{abstract}

KEY WORDS: Zostera marina $\cdot$ Mytilus edulis · Eco-engineering · Facilitation · Transplantation · Wadden Sea

\section{INTRODUCTION}

The cosmopolitan eelgrass Zostera marina Linneaus suffered greatly from 'wasting' disease in the 1930s (Giesen et al. 1990a, de Jonge et al. 2000), when 1000s of hectares were destroyed. Natural recovery of eelgrass was poor in the western Wadden Sea, probably due to intensive engineering activities, turbidity in the water column, fishing activities (Giesen et al. 1990b, de Jonge et al. 2000) and increased nutrient loads in the 1970s and 1980s (van Katwijk et al. 1997, 1999, 2000). By that time, the abundance of eelgrass in the Wadden Sea had been reduced to less than $1 \%$ of the level in the 1930s (de Jonge et al. 2000). In the 1990s, water quality improved and the clarity of the water column increased again (van Katwijk et al. 2000), but eelgrass did not recover in the western Wadden Sea. The remnant annual populations of intertidal eelgrass in the eastern part of the Wadden Sea may not have been able to supply seeds to western locations, due to predominantly westerly winds and currents.

Eelgrass is highly appreciated for its ecological role in tidal flats. At high tide, eelgrass forms a complex structure that creates shelter for juvenile fishes and invertebrates (Jenkins et al. 1997, Heck et al. 2003, Polte et al. 2005). Intertidal eelgrass is emergent at low 
tide and provides rich meadows that are especially valuable for foraging birds (Nienhuis \& van Ierland 1978). In addition to these ecological functions, eelgrass is known to increase sedimentation (e.g. Gambi et al. 1990), stabilise tidal mud flats and may contribute to coastal protection (e.g. Hughes \& Paramor 2004). The combination of ecological and eco-engineering functions makes eelgrass a key species for habitat restoration.

Restoration programmes have studied eelgrass density in relationship to survival and growth. At high seeding density (300 to 1600 germinated seeds $\mathrm{m}^{-2}$, Granger et al. 2000), or high planting density (60 to 125 seedlings $\mathrm{m}^{-2}$, van Katwijk et al. 1998), lateral shoot expansion is reduced with increasing density. At lower planting density (10 to 25 plants $\mathrm{m}^{-2}$, Worm \& Reusch 2000) positive interactions among eelgrass shoots appear to be more important than competitive processes during the first period after transplantation. Olesen \& Sand-Jensen (1994) found that eelgrass mortality declined with increasing numbers of eelgrass shoots, probably due to mutual physical protection. This was confirmed by studies of $\mathrm{T}$. Bouma (unpubl. data), who showed experimentally that one eelgrass plant facilitates another by reducing drag force. From this we hypothesised that a relatively high planting density is favourable to transplantations at relatively exposed sites, whereas planting density will not influence transplantation success at sheltered locations.
In intertidal locations, total exposure to waves and currents increases with duration of immersion. In the Wadden Sea, eelgrass is generally not found below $-0.20 \mathrm{~m}$ mean sea level (MSL), although light is not limiting down to $-0.80 \mathrm{~m}$ MSL (van Katwijk et al. 1998, van Katwijk \& Hermus 2000). However, eelgrass grows at deeper locations when in the proximity of mussel beds (van Katwijk \& Hermus 2000, van Katwijk et al. 2000). Laboratory experiments, as well as field observations, indicate that seagrass beds may be facilitated by mussel beds, which reduce hydrodynamic stress forces (Reusch \& Chapman 1995, van Katwijk et al. 2000, T. Bouma unpubl.).

The present study aimed to test experimentally the relationship between survival and density of eelgrass transplants at locations of differing exposure to waves and currents, and to describe the effect of mussel bed presence on transplant survival.

\section{MATERIALS AND METHODS}

Location selection. Location selection is considered the most important phase among restoration practices (Fonseca et al. 2002, van Katwijk \& Wijgergangs 2004). Therefore, we gave considerable attention to this activity. Three locations (B1, B2 and B3) with varied exposure times to currents and waves were selected in the intertidal Balgzand area of the western Wadden Sea (Fig. 1). This area formerly supported eelgrass, is

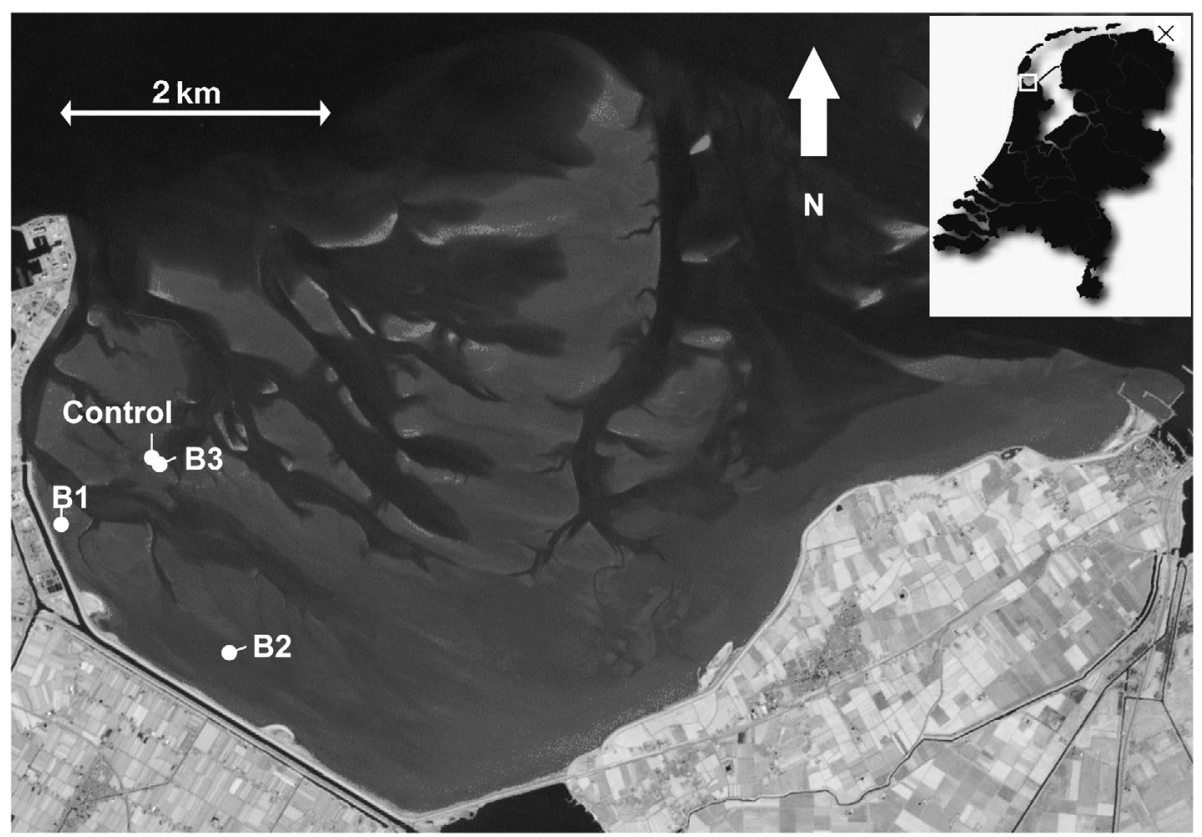

Fig. 1. The Balgzand area (Landsat satellite photograph) with 3 planting locations (B1 to B3) and a control site (Control). In the upper right corner, the white square shows the position of the Balgzand area in relation to the Netherlands as a whole. The $\times$ in the eastern part of the Wadden Sea, represents the donor population in the Ems estuary 
Table 1. Experimental treatment combinations: locations (see Fig. 1), number of planting units, distance to shore, duration of hydrodynamic exposure per tidal cycle (duration of immersion), median sediment grain size $(+\mathrm{SD})$ and class of exposure. HD = high density $\left(14\right.$ plants $\left.\mathrm{m}^{-2}\right) ; \mathrm{LD}=$ low density $\left(5\right.$ plants $\left.\mathrm{m}^{-2}\right)$; MSL: mean sea level

\begin{tabular}{|c|c|c|c|c|c|c|}
\hline Location & $\begin{array}{l}\text { Number of } \\
\text { planting units }\end{array}$ & $\begin{array}{l}\text { Distance to } \\
\text { shore }(\mathrm{m})\end{array}$ & $\begin{array}{l}\text { MSL } \\
(\mathrm{cm})\end{array}$ & $\begin{array}{c}\text { Duration of hydrodynamic } \\
\text { exposure }(\mathrm{h})\end{array}$ & $\begin{array}{l}\text { Grain size } \\
\qquad(\mu \mathrm{m})\end{array}$ & $\begin{array}{l}\text { Class of } \\
\text { exposure }\end{array}$ \\
\hline B1 & $3 \mathrm{HD}+3 \mathrm{LD}$ & 75 & +4 & 5.3 & $63.9(6.7)$ & Low \\
\hline B2 & $6 \mathrm{HD}+6 \mathrm{LD}$ & 610 & +4 & 5.3 & $134.9(5.9)$ & Intermediate \\
\hline B3 & $6 \mathrm{HD}+6 \mathrm{LD}$ & 1840 & -40 & 7.8 & $112.3(11.3)$ & High \\
\hline Control & $3 \mathrm{HD}$ & 1880 & -40 & 7.8 & $128.9(4.7)$ & High \\
\hline
\end{tabular}

protected from the prevailing westerly winds, has no fishing activities (van Katwijk et al. 2000), and was therefore expected to have high potential for eelgrass restoration. All locations had a mean tidal range from -81 to $+58 \mathrm{~cm}$ MSL.

Location B1 was situated in close proximity to the seawall (Fig. 1). Its suitability for eelgrass restoration was proven by the presence of a number of eelgrass plants that had survived since a seeding experiment carried out in 1999. Location B1 had a mean depth of about $+4 \mathrm{~cm}$ MSL (Table 1). Location B2 was situated about $610 \mathrm{~m}$ from the seawall and had a mean depth of $+4 \mathrm{~cm}$ MSL (Table 1). Preliminary experiments in 1993 and 1994 showed that eelgrass could survive at this location. Location B3 (Fig. 1) was located at a mean depth of $-40 \mathrm{~cm}$ MSL to ensure a longer immersion time, and thus longer hydrodynamic exposure for the transplants (maximum wave energy is equal within the depth range of the 3 locations; van Katwijk \& Hermus 2000). All of the sites were shallower than the compensation depth for eelgrass in this area of the Wadden Sea (-80 cm MSL; van Katwijk et al. 1998, van Katwijk \& Hermus 2000). To study the effect of the presence of a mussel bed on transplant survival, eelgrass shoots were transplanted within the open spaces of a blue mussel bed (Mytilus edulis L., approx. $2500 \mathrm{~m}^{2}$ ) at Location B3 and at a control location $60 \mathrm{~m}$ seaward of the mussel bed (all located at a mean depth of $-40 \mathrm{~cm}$ MSL, Fig. 1).

Collection, transport and planting of seedlings. Eelgrass seedlings were dug out by hand from the tidal flat 'Hond/Paap' in the Ems estuary, eastern Dutch Wadden Sea (Fig. 1), on 10 and 11 June 2003. Attached sediment was removed by gently washing the roots. The seedlings were collected separately, each from an area of approximately $9 \mathrm{~m}^{2}$, which ensured genetic diversity in the eelgrass plants (Olsen et al. 2004). The seedlings were put in large plastic bags along with the water attached to them, thus avoiding drying out. Subsequently, they were stored and transported in a cool box at an average temperature of $11^{\circ} \mathrm{C}$. Seedlings consisted of a single vegetative shoot with leaf lengths between 8 and $21 \mathrm{~cm}$. Individuals were selected randomly for planting locations.
Translocation to Locations B1 and B2 was carried out on 11 June 2003, and on 12 June 2003 at Location B3 and its control location $60 \mathrm{~m}$ seaward of the mussel bed. Thirty-seven seedlings were transplanted into a hexagonal bed (Fig. 2) making up a planting unit. The mutual distance between plants was chosen to resemble that of natural populations in the Dutch Wadden Sea: $30 \mathrm{~cm}$ distant for high density treatments $(\mathrm{HD}=$ 14 plants $\mathrm{m}^{-2}$ ), and $50 \mathrm{~cm}$ distant for low density treatments (LD $=5$ plants $\mathrm{m}^{-2}$ ) (Fig. 2). HD and LD planting units were always located in pairs, but in different numbers per location (Table 1). The baseline of all pairs was positioned at a compass bearing of $50^{\circ}$ to ensure that HD and LD planting units were similarly exposed to the prevailing tidal currents. At Location B3, planting units were positioned in depressions of the mussel bed.

Monitoring. Planting units were monitored regularly from transplantation until the end of October 2003. A weekly code was introduced, because locations were

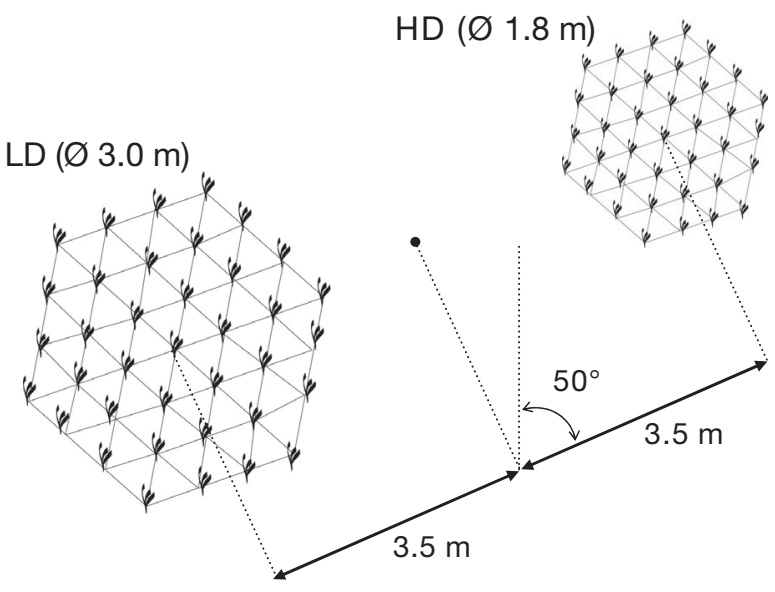

Fig. 2. Planting units with eelgrass seedlings at low density (LD) and high density (HD). Planting unit diameter and mutual distance are indicated. The planting unit-pair axis was positioned at a compass bearing of $50^{\circ}$ to guarantee similar exposure to the prevailing tidal currents. Black dot in the center represents a small bamboo stick that helped locate the site during monitoring 
monitored, in part, on subsequent days. The transplantation was set at Week 0. Plants were counted on all monitoring dates to quantify survival. The developmental stage of each surviving plant was also recorded in Weeks 5 and 11, using the following categories: (1) no reproductive shoots, (2) reproductive shoots without flowers, (3) reproductive shoots with flowers, (4) reproductive shoots with seeds. Although a plant could have reproductive shoots from more than one of these categories, it was categorised by its latest developmental category. Percentage plant cover was visually estimated in Weeks 0 and 11.

The lengths of both the vegetative and reproductive shoots, and the leaf widths were measured on 4 shoots per plant for at least 4 plants per planting unit on 9 September 2003 (Week 13). These measurements could not be carried out at Location B3 because an insufficient number of plants was available at that time.

Exposure. The locations (differently exposed to wave dynamics) were classified on the basis of sediment grain size (Granata et al. 2001), distance to the shore, and the duration of hydrodynamic exposure (= duration of immersion; van Katwijk \& Hermus 2000). To measure grain size, three $10 \mathrm{~cm}$ long sediment cores with a diameter of $2.8 \mathrm{~cm}$ were collected close to each planting unit and combined before storage at $-18^{\circ} \mathrm{C}$. The samples were freeze-dried and sieved $(1 \mathrm{~mm})$, to remove small pieces of shell, and were analysed with a Malvern Laser Particle Sizer. Median grain size of the sediment at Locations B2, B3 and Control was about double that at Location B1 (Table 1). Location B1 was relatively close to shore, whereas Locations B3 and Control were furthest away from shore (Table 1). Moreover, Locations B1 and B2 were exposed to hydrodynamic forces for $2.5 \mathrm{~h}$ less per tidal cycle than Locations B3 and Control (Table 1). Combining these results indicates that hydrodynamic exposure was low at Location B1, intermediate at Location B2 and high at Locations B3 and Control.

Statistical analyses. The relatively low number (3 or 6) of replicates (each planting unit was considered as an experimental unit) prevented proof of homogeneity of variances in the data in most cases. Therefore, statistical tests were carried out with the non-parametric Mann Whitney $U$-test for each monitoring occasion. Survival curves were calculated for each location and density using Kaplan-Meier survival analysis, accounting for the survival of every individual plant. Subsequently, the log rank test was used to test the null hypothesis that there was no difference in the probability of plant loss between planting densities and/or locations during the observation period. Statistical tests were calculated using SPSS software (Version 11.5). Data were graphically presented with box-whisker plots using Sigma Plot (Version 9).

\section{RESULTS}

\section{Transplant survival and plant cover}

In total, 1221 eelgrass seedlings were transplanted, and their survival varied greatly between the locations (Fig. 3). At Location B1 survival was relatively high and stable, with a median of $76 \%$ from Week 3 until Week 7. Transplant survival curves were not significantly different (log rank test; $\mathrm{p}>0.05$ ) between the HD and LD planting units at this location.

Survival of the transplants at Location B2 was relatively high, with a median of at least $54 \%$ until Week 11 (Fig. 3). The survival curves of HD and LD planting units were significantly different (log rank test; $\mathrm{p}<$ 0.05), with higher survival in HD planting units. Most
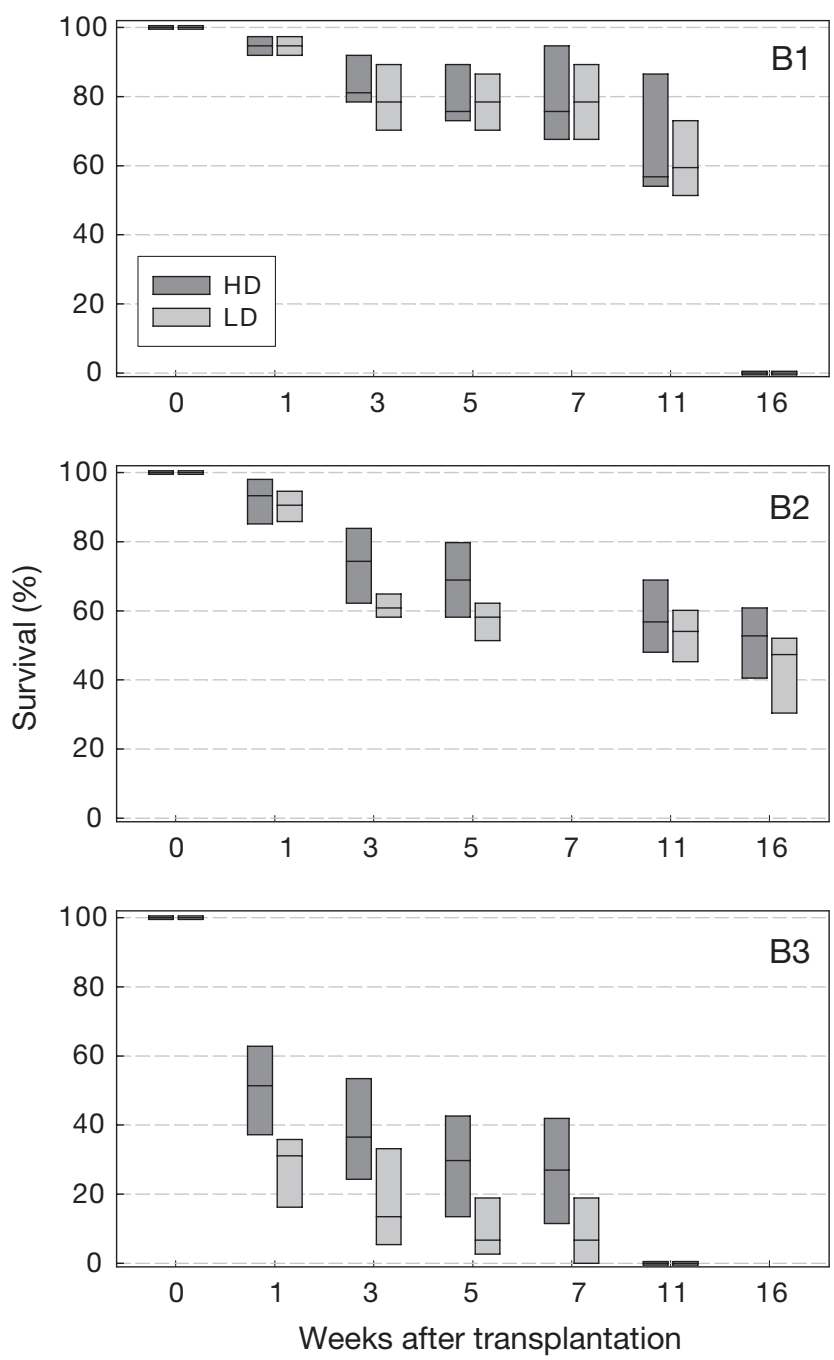

Fig. 3. Zostera marina. Survival of transplants (median, upper and lower quartiles) at Locations B1, B2 and B3. Loss of transplants at Location B1 in Week 16 was probably caused by accumulated macroalgae 
of the plants survived until the beginning of fall, in contrast to observations at Locations B1 and B3.

Survival of the transplants at Location B3 was relatively low (Fig. 3). Less than $50 \%$ survived the first week. During the following weeks, lower numbers of plants disappeared, while the survivors started to develop. Significantly higher survival (log rank test; $\mathrm{p}<0.01$ ) was found in HD planting units than in LD planting units.

Survival at both densities of transplants was significantly higher at Locations B1 and B2 than at Location B3 (log rank test; $\mathrm{p}<0.01$ ). In the LD planting units, survival during the growing season at Location B1 was significantly higher than at Location B2 (log rank test; $\mathrm{p}<0.01$ ). This was not the case for the HD planting units at the 2 locations (log rank test; $p>0.05$ ).

The difference between survival of transplants within a mussel bed and survival of transplants at the control location $60 \mathrm{~m}$ seaward increased during the observation period (Fig. 4). The survival curve of the transplants within the mussel bed was significantly higher (log rank test; $\mathrm{p}<0.05$ ) than that of the transplants at the control location. All plants had disappeared by Week 11.

Plant cover was less than $5 \%$ at all locations after transplantation in Week 0. However, cover increased towards the end of the growing season, and ranged between 14 and $52 \%$ in Week 11 (Table 2). Plant cover was not significantly different between HD and LD planting units (Mann Whitney $U$-test; $p$ >0.05) at all locations in Week 11, when corrected for the initial density differences and expressed as absolute covered area. Mean plant cover was calculated at $487 \mathrm{~cm}^{2}$ in Week 11, which resulted in a mean plant diameter of $25 \mathrm{~cm}$, considering a plant as a circular unit.

\section{Reproductive shoots}

Reproductive shoots had developed in about $80 \%$ of all transplants at Locations B1 and B2 by Week 5 (Fig. 5). This percentage was much lower at Location B3 (ca. 20\%). There were no significant differences between HD and LD planting units (Mann Whitney $U$ -

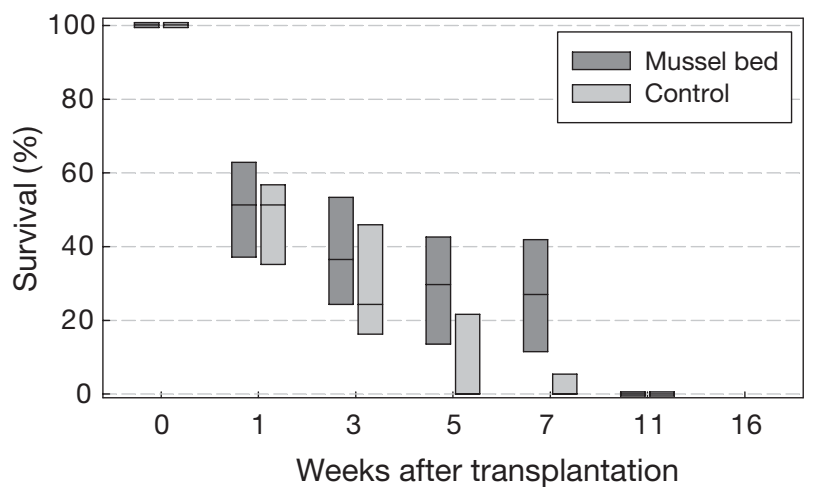

Fig. 4. Zostera marina and Mytilus edulis. Survival of eelgrass transplants (median, upper and lower quartiles) at Location B3 within a mussel bed and at a control location without mussels

test; $\mathrm{p}>0.05)$. In Week 5, most of the reproductive shoots were at the non-flowering stage at all locations (Fig. 5). Reproductive shoots did not bear seeds.

In Week 11, almost all plants had developed reproductive shoots at Locations B1 and B2 (Fig. 5). Again no significant differences were observed between HD and LD planting units (Mann Whitney $U$-test; $\mathrm{p}>0.05$ ). The majority of the reproductive shoots at all locations bore flowers (Fig. 5). The percentage of non-flowering reproductive shoots was 8 and $22 \%$ at Locations B1 and B2, respectively. Reproductive shoots did not bear seeds. No plants were present at Location B3 in Week 11 (Fig. 5).

\section{Shoot length and leaf width}

The length of reproductive shoots was about $50 \mathrm{~cm}$ at Locations B1 and B2 in Week 13 (Table 2). There were no significant pairwise differences between HD and LD at each location (Mann Whitney $U$-test; $\mathrm{p}>0.05$ ). However, when data were pooled across locations, there were significantly longer reproductive shoots in LD planting units (Mann Whitney $U$-test; $\mathrm{p}<0.05$ ).

The length of vegetative shoots was about $15 \mathrm{~cm}$ at Location B1 and $30 \mathrm{~cm}$ at Location B2 in Week 13

Table 2. Mean $( \pm \mathrm{SD})$ plant cover, length and width of reproductive and vegetative shoots in high density (HD) and low density (LD) planting units at Locations B1 and B2. Plant cover was estimated in Week 11, whereas other parameters were measured in Week 13 after transplantation

\begin{tabular}{|lccccc|}
\hline Location & Density & Plant cover & \multicolumn{2}{c|}{ Vegetative shoots } & \multicolumn{2}{c|}{$\begin{array}{c}\text { Reproductive shoots } \\
\text { Length }(\mathrm{cm})\end{array}$} \\
\hline B1 & & Length (cm) & Width (mm) & $2.6(0.6)$ & $48.8(11.8)$ \\
& HD & $51.7(29.3)$ & $19.4(6.0)$ & $2.7(0.8)$ & $51.9(4.4)$ \\
B2 & LD & $23.3(16.1)$ & $13.0(2.7)$ & $3.1(0.7)$ & $51.2(8.1)$ \\
& HD & $37.5(13.7)$ & $29.4(5.9)$ & $3.3(0.5)$ & $53.6(8.8)$ \\
\hline
\end{tabular}



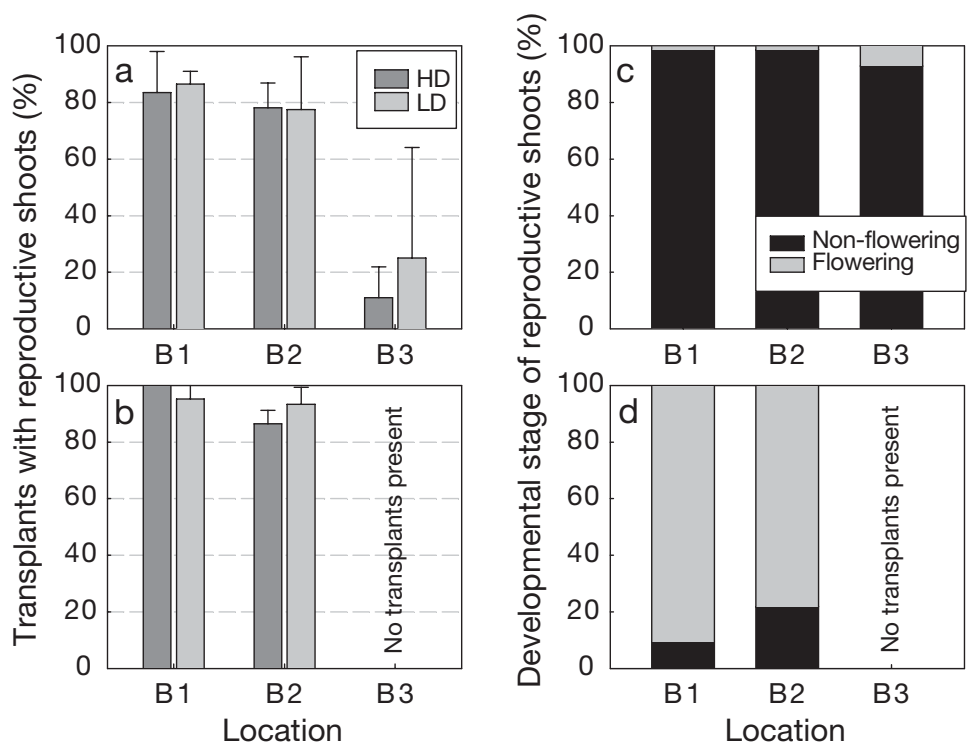

Fig. 5. Mean percentage of transplants with reproductive shoots in high density (HD) and low density (LD) planting units (a) in Week 5 after transplantation and (b) in Week 11 after transplantation. Developmental stage of reproductive shoots within categories 'non-flowering' and 'flowering' (c) in Week 5 after transplantation and (d) in Week 11 after transplantation. No transplants were present at Location B3 in Week 11

(Table 2). The length of vegetative shoots was not significantly different between HD and LD planting units (Mann Whitney $U$-test; $\mathrm{p}>0.05$ ). However, the vegetative shoots were significantly longer at Location B2 than at Location B1 for both HD and LD planting units (Mann Whitney $U$-test; $\mathrm{p}<0.05$ ).

Leaf width ranged from roughly 2 to $4 \mathrm{~mm}$ in Week 13 at all locations (Table 2). There were no significant differences between HD and LD planting units (Mann Whitney $U$-test; $\mathrm{p}>0.05$ ). However, all leaves were significantly wider at Location B2 than at Location B1 (Mann Whitney $U$-test; p < 0.01).

\section{DISCUSSION}

\section{Transplant survival and development}

Seagrass transplantations have been carried out world-wide and studied for decades (e.g. Worm \& Reusch 2000, Short et al. 2002). It is a common phenomenon in transplantation experiments that the total number of transplants decreases logarithmically towards a stable number during the first weeks after planting (Fonseca et al. 1998). This was observed in previous transplantation experiments in the Wadden Sea (van Katwijk \& Hermus 2000, van Katwijk \& Wijgergangs 2004) and in the present study (Fig. 3). Survival of transplants was calculated to fluctuate around a median of $35 \%$ in 53 North American sea- grass transplantation studies (Fonseca et al. 1998). After 3 wk, during the present study, 76,68 and $28 \%$ of the transplants survived at the locations with low, intermediate and high exposure to currents and waves, respectively. This confirms that hydrodynamic exposure is unfavourable for transplant survival, which is also the case for natural eelgrass beds (e.g. Fonseca \& Bell 1998, van Katwijk \& Hermus 2000). Similarly, Schanz \& Asmus (2003) concluded from transplantation experiments in natural Zostera noltii beds in the Wadden Sea that strong hydrodynamics directly affect the development and architecture of these beds by decreasing seagrass density and changing shoot morphology.

After successful acclimation, seedlings start a growth period in which biomass increases markedly. This growth period can be recognised by a stabilisation of the total number of surviving transplants. This occurred at the low and intermediate exposure locations, where survival was relatively constant during a period of $7 \mathrm{wk}$ or even longer (Fig. 3). Despite growth and attainment of the flowering stage, plants disappeared at the high exposure location, due to unfavourable environmental conditions. Nevertheless, plant cover reached a mean maximum of $52 \%$ (Table 2) and flowering shoots were found in over $80 \%$ of the transplants by Week 11, confirming overall transplant development during the growing season.

Shoot morphology of Zostera noltii in the eastern Wadden Sea changed when plants were relocated from an exposed to a sheltered site in a natural seagrass bed (Schanz \& Asmus 2003). In the present study, transplanted eelgrass shoots and leaves were significantly longer and wider at the intermediate exposure location than at the low exposure location. Schanz et al. (2002) found higher grazer densities at sheltered sites than at exposed sites, and herbivory may have reduced epiphyte cover, thus increasing growth of $Z$. noltii leaves. However, higher or similar densities of grazers occur at Location B1 than at Location B2 (Bos \& van Katwijk 2005). The reduced shoot and leaf sizes at the low exposure location may have been caused by accumulating mats of floating macroalgae that regularly covered the planting units (Bos \& van Katwijk 2005).

\section{Planting density}

The planting densities ( 5 and 14 seedlings $\mathrm{m}^{-2}$ ) used in the present study seem low compared to natural eelgrass populations around the world. However, they 
were chosen to resemble natural eelgrass densities in the Wadden Sea, as observed during recent decades. In the Ems estuary, a mean density of 2 to 4 seedlings $\mathrm{m}^{-2}$ occurs (Erftemeijer 2004). There are slightly higher densities of 2 to 10 and 20 to 30 seedlings $\mathrm{m}^{-2}$ on Terschelling Island and Sylt Island, respectively (M. M. van Katwijk, R. de Vries \& P. Kennis unpubl.). Also, eelgrass populations in southern Dutch waters have mean densities ranging from 4 to 25 seedlings $\mathrm{m}^{-2}$ (Harrison 1993). These relatively low seedling densities may be related to the annual reproductive strategy of the eelgrass populations in the Wadden Sea.

Eelgrass development is limited by competitive effects at densities of $>60$ plants $\mathrm{m}^{-2}$ (van Katwijk et al. 1998, Granger et al. 2000). In the range of 10 to 25 plants $\mathrm{m}^{-2}$, increased density enhances plant survival and development in the Baltic Sea (Worm \& Reusch 2000). Our study testing densities of 5 and 14 plants $\mathrm{m}^{-2}$ corroborates this. At intermediate or relatively high exposure to wave dynamics, plant survival was higher at HD than at LD. The effect was strongest at the site with the highest exposure during summer, where the survival at a density of 14 plants $\mathrm{m}^{-2}$ was about double that at a density of 5 plants $\mathrm{m}^{-2}$. No density effects occurred at the low exposure location, which confirms the hypothesis that planting density does not affect transplantation success at sheltered locations. This also provides experimental field evidence for the laboratory observations of $\mathrm{T}$. Bouma (unpubl. data) that one eelgrass plant facilitates another by reducing drag force when exposed to currents. Olesen \& Sand-Jensen (1994) also suggest that the correlation between declining eelgrass mortality and increasing numbers of eelgrass shoots is probably due to mutual physical protection. Competitive effects between adjacent plants may not have been important during the present study, as the estimated diameter of a plant $(25 \mathrm{~cm})$ at the end of the growing season was lower than the initial distance between seedlings in the high density planting units $(30 \mathrm{~cm})$.

\section{Blue mussel interaction}

Co-occurrence of mussels and eelgrass has been described as both mutualism (e.g. Peterson \& Heck 2001a,b) and competition (e.g. Reusch \& Williams 1998, Allen \& Williams 2003). Blue mussels alter their environment in several ways and may affect eelgrass growth or survival by doing so. Reusch et al. (1994) found that sediment porewater concentrations of ammonium and phosphate in the western Baltic doubled in the presence of blue mussels Mytilus edulis, and suggested that the mussels fertilise eelgrass growth by the deposition of faeces and pseudo-faeces.
However, in the Wadden Sea, ammonium and phosphate concentrations are relatively high (van Katwijk et al. 2000) and, therefore, an additional fertilizing effect by mussels does not explain the enhanced survival of transplants. Mussel beds also reduce turbidity of the water column (Beukema \& Cadée 1996, Newell \& Koch 2004), but the mussel bed in the present study was probably too small to have generated such an effect.

A combination of the processes described above results in increased sedimentation, stabilisation of sediments and a reduced mean grain size of the sediment within mussel beds (Flemming \& Delafontaine 1994, Meadows et al. 1998, Widdows \& Brinsley 2002). Losses of eelgrass seeds may be lower at locations where this combination of processes operates, leading to increased germination rates, but development and/ or survival of eelgrass transplants are unlikely to be affected similarly.

Although the factors described above may play a role in the distribution of eelgrass, they do not explain why eelgrass transplants survive better in a mussel bed than outside. Mussel beds generally protrude several tens of $\mathrm{cm}$ above the sediment surface and reduce wave and current activity (e.g. Flemming \& Delafontaine 1994, Widdows \& Brinsley 2002). The occurrence of intertidal eelgrass at hydrodynamically more exposed locations when positioned behind a mussel bed suggested a facilitative effect of mussels on seagrasses in the Wadden Sea. Because a similar effect occurs when seagrasses are sheltered by a dam, facilitation by mussels was expected to be related primarily to the reduction of hydrodynamic forces from waves and/or from tidal currents (van Katwijk \& Hermus 2000). Sheltered habitats within mussel beds (Nehls \& Thiel 1993, Reise 1998, van de Koppel et al. 2005) may permit eelgrass survival at greater depth than hydrodynamic forces would generally allow (van Katwijk \& Hermus 2000, van Katwijk et al. 2000). T. Bouma (unpubl. data) found experimentally that blue mussels facilitate eelgrass by reducing drag force on shoots exposed to currents. We tested this relationship at a relatively exposed location where transplanted eelgrass shoots had a significantly higher survival in a mussel bed than outside (Fig. 4). However, all plants disappeared during the growing season and it seemed that there is a threshold for wave and current activity. This would indicate that protection by the mussel bed was present, but insufficient to support long-term survival. In the same manner, mussel beds in the Baltic Sea protect eelgrass during moderate storms, but not in intense storms (Reusch \& Chapman 1995).

In the Wadden Sea, seagrass and mussel beds are frequently located close to one another, and seagrass habitat suitability maps have shown overlap (e.g. 
Nehls \& Thiel 1993, Bos et al. 2005). Both eelgrass and mussels occur in relatively sheltered areas (e.g. behind barrier islands); however, mussel beds usually grow deeper than seagrasses (the upper limit of mussel beds is $0 \mathrm{~cm} \mathrm{MSL).} \mathrm{Therefore,} \mathrm{facilitation} \mathrm{could} \mathrm{have} \mathrm{high}$ ecological value and its role may have been underestimated.

In summary, survival of eelgrass transplants is highly dependent on the interaction of planting density and relative exposure to water dynamics. At low exposure, planting density had no effect, while at more exposed locations planting density had an increasingly positive effect. Moreover, facilitation by mussel beds enhances survival of eelgrass seedlings in highly exposed habitats. Our results provide experimental field evidence for facilitation among eelgrass plants (planting density effects) and by mussel beds. This knowledge will be extremely useful for the experimental design of future transplantation programmes.

Acknowledgements. We are grateful to S. Braaksma, N. Dankers, K. Essink, A. Groeneweg, K. Groenveld, C. Hermus, Z. Jager, D. J. de Jong, A. Nicolai, S. van Pelt, T. Smit, J. de Vlas, M. van Wieringen, the Stichting Landschap Noord-Holland, the crew of the vessel 'Phoca' and many students for their contribution to conceptual discussions and/or field work. We thank T. de Boo (Dept. Epidemiology and Biostatistics, Radboud University Nijmegen) who advised us on the statistical analyses. Sediment analyses were carried out at the Netherlands Institute for Ecological Research by W. Suykerbuyk under supervision of T. Bouma and M. Houtekamer. The project was funded by the Directorate for Public Works and Water Management in the Netherlands. Suggestions of 2 anonymous reviewers helped to improve the manuscript.

\section{LITERATURE CITED}

Allen BJ, Williams SL (2003) Native eelgrass Zostera marina controls growth and reproduction of an invasive mussel through food limitation. Mar Ecol Prog Ser 254:57-67

Beukema JJ, Cadée GC (1996) Consequences of the sudden removal of nearly all mussels and cockles from the Dutch Wadden Sea. PSZN I: Mar Ecol 17:279-289

Bos AR, van Katwijk MM (2005) Herintroductie van Groot zeegras (Zostera marina) in de westelijke Waddenzee (2002-2005). Eindrapportage. Afdeling Milieukunde, Radboud Universiteit Nijmegen

Bos AR, Dankers N, Groeneweg AH, Hermus DCR and 6 others (2005) Eelgrass (Zostera marina L.) in the western Wadden Sea: monitoring, habitat suitability model, transplantations and communication. Vlaams Inst Zee Spec Pub 19:95-109

de Jonge VN, de Jong DJ, van Katwijk MM (2000) Policy plans and management measures to restore eelgrass (Zostera marina L.) in the Dutch Wadden Sea. Helgol Mar Res 54:151-158

Erftemeijer PLA (2004) Herstel van zeegrasvelden in de Nederlandse Waddenzee: de rol van zaadtransport. Report 3756, WLIDelft Hydraulics, Delft

Flemming BW, Delafontaine MT (1994) Biodeposition in a juvenile mussel bed of the east Frisian Wadden Sea (southern North Sea). Neth J Aquat Ecol 28:289-297
Fonseca MS, Bell SS (1998) Influence of physical setting on seagrass landscapes near Beaufort, North Carolina, USA. Mar Ecol Prog Ser 171:109-121

Fonseca MS, Kenworthy WJ, Thayer GW (1998) Guidelines for the conservation and restoration of seagrasses in the United States and adjacent waters. NOAA Coastal Oceans Program Decision Analysis Series No. 12. NOAA Coastal Ocean Office, Silver Spring, MD

Fonseca MS, Kenworthy WJ, Julius BE, Shutler S, Fluke S (2002) Seagrasses. In: Perrow MR, Davy AJ (eds) Handbook of ecological restoration, Vol 2. Restoration in practice. Cambridge University Press, Cambridge, p 149-170

Gambi MC, Nowell ARM, Jumars PA (1990) Flume observations on flow dynamics in Zostera marina (eelgrass) beds. Mar Ecol Prog Ser 61:159-169

Giesen WBJT, van Katwijk MM, den Hartog C (1990a) Temperature, salinity, insolation and wasting disease of eelgrass (Zostera marina L.) in the Dutch Wadden Sea in the 1930s. Neth J Sea Res 25:395-404

Giesen WBJT, van Katwijk MM, den Hartog C (1990b) Eelgrass condition and turbidity in the Dutch Wadden Sea. Aquat Bot 37:71-85

Granata TC, Serra T, Colomer J, Casamitjana X, Duarte CM, Gacia E (2001) Flow and particle distribution in a nearshore seagrass meadow before and after a storm. Mar Ecol Prog Ser 218:95-106

Granger SL, Traber MS, Nixon SW (2000) The influence of planning depth and density on germination and development of Zostera marina seeds. Biol Mar Medit 7:55-58

Harrison PG (1993) Variations in demography of Zostera marina and Zostera noltii on an intertidal gradient. Aquat Bot 45:63-77

Heck KL, Hays G, Orth RJ (2003) Critical evaluation of the nursery role hypothesis for seagrass meadows. Mar Ecol Prog Ser 253:123-136

Hughes RG, Paramor OAL (2004) On the loss of saltmarshes in south-east England and methods for their restoration. J Appl Ecol 41:440-448

Jenkins GP, May HMA, Wheatley MJ, Holloway MG (1997) Comparison of fish assemblages associated with seagrass and adjacent unvegetated habitats of Port Phillip Bay and Corner Inlet, Victoria, Australia, with emphasis on commercial species. Estuar Coast Shelf Sci 44: $569-588$

Meadows PS, Meadows A, West FJC, Shand PS, Shaikh MA (1998) Mussels and mussel beds (Mytilus edulis) as stabilizers of sedimentary environments in the intertidal zone. In: Black KS, Paterson DM, Cramp A (eds) Sedimentary processes in the intertidal zone. Geological Society, London, p 331-347

Nehls G, Thiel M (1993) Large-scale distribution patterns of the mussel Mytilus edulis in the Wadden Sea of Schleswig-Holstein-do storms structure the ecosystem? Neth J Sea Res 31:181-187

Newell RIE, Koch EW (2004) Modeling seagrass density and distribution in response to changes in turbidity stemming from bivalve filtration and seagrass sediment stabilization. Estuaries 27:793-806

Nienhuis PH, van Ierland ET (1978) Consumption of eelgrass, Zostera marina, by birds and invertebrates during the growing season in Lake Grevelingen (SW Netherlands). Neth J Sea Res 12:180-194

Olesen B, Sand-Jensen K (1994) Patch dynamics of eelgrass Zostera marina. Mar Ecol Prog Ser 106:147-156

Olsen JL, Stam WT, Coyer AJ, Reusch TBH and 14 others (2004) North Atlantic phylogeography and large-scale 
population differentiation of the seagrass Zostera marina L. Mol Ecol 13:1923-1941

Peterson BJ, Heck KL Jr (2001a) Positive interactions between suspension-feeding bivalves and seagrass - a facultative mutualism. Mar Ecol Prog Ser 213:143-155

Peterson BJ, Heck KL Jr (2001b) An experimental test of the mechanism by which suspension feeding bivalves elevate seagrass productivity. Mar Ecol Prog Ser 218:115-125

Polte P, Schanz A, Asmus H (2005) The contribution of seagrass beds (Zostera noltii) to the function of tidal flats as a juvenile habitat for dominant, mobile epibenthos in the Wadden Sea. Mar Biol 147:813-822

Reise K (1998) Pacific oysters invade mussel beds in European Wadden Sea. Senckenb Marit 28:167-175

Reusch TBH, Chapman ARO (1995) Storm effects on eelgrass (Zostera marina L.) and blue mussel (Mytilus edulis L.) beds. J Exp Mar Biol Ecol 192:257-271

Reusch TBH, Williams SL (1998) Variable responses of native eelgrass Zostera marina to a non-indigenous bivalve Musculista senhousia. Oecologia 113:428-441

Reusch TBH, Chapman ARO, Gröger JP (1994) Blue mussels Mytilus edulis do not interfere with eelgrass Zostera marina but fertilize shoot growth through biodeposition. Mar Ecol Prog Ser 108:265-282

Schanz A, Asmus H (2003) Impact of hydrodynamics on development and morphology of intertidal seagrasses in the Wadden Sea. Mar Ecol Prog Ser 261:123-134

Schanz A, Polte P, Asmus H (2002) Cascading effects of hydrodynamics on a epiphyte-grazer system in intertidal seagrass beds of the Wadden Sea. Mar Biol 141: 287-297

Short FT, Davis RC, Kopp BS, Short CA, Brudick DM (2002) Site-selection model for optimal transplantation of eelgrass Zostera marina in the northeastern US. Mar Ecol

Editorial responsibility: Victor de Jonge (Contributing Editor), Haren, The Netherlands
Prog Ser 227:253-267

van de Koppel J, Rietkerk M, Dankers N, Herman PMJ (2005) Scale-dependent feedback and regular spatial patterns in young mussel beds. Am Nat 165:E66-E77

van Katwijk MM, Hermus DCR (2000) Effects of water dynamics on Zostera marina: transplantation experiments in the intertidal Dutch Wadden Sea. Mar Ecol Prog Ser 208:107-118

van Katwijk MM, Wijgergangs LJM (2004) Effects of locally varying exposure, sediment type and low-tide water cover on Zostera marina recruitment from seed. Aquat Bot 80: $1-12$

van Katwijk MM, Vergeer LHT, Schmitz GHW, Roelofs JGM (1997) Ammonium toxicity in eelgrass Zostera marina. Mar Ecol Prog Ser 157:159-173

van Katwijk MM, Schmitz GHW, Hanssen LSAM, den Hartog C (1998) Suitability of Zostera marina populations for transplantation to the Wadden Sea as determined by a mesocosm shading experiment. Aquat Bot 60:283-305

van Katwijk MM, Schmitz GHW, Gasseling AM, van Avesaath PH (1999) The effects of salinity and nutrient load and their interaction on Zostera marina L. Mar Ecol Prog Ser 190:155-165

van Katwijk MM, Hermus DCR, de Jong DJ, Asmus RM, de Jonge VN (2000) Habitat suitability of the Wadden Sea for restoration of Zostera marina beds. Helgol Mar Res 54: $117-128$

Widdows J, Brinsley M (2002) Impact of biotic and abiotic processes on sediment dynamics and the consequences to the structure and functioning of the intertidal zone. J Sea Res 48:143-156

Worm B, Reusch TBH (2000) Do nutrient availability and plant density limit seagrass colonization in the Baltic Sea? Mar Ecol Prog Ser 200:159-166

Submitted: December 22, 2005; Accepted: September 19, 2006 Proofs received from author(s): April 11, 2007 